\title{
Fermented Dairy Products: Starter Cultures and Potential Nutritional Benefits
}

\author{
Parmjit S. Panesar \\ Department of Food Engineering \& Technology, Sant Longowal Institute of Engineering \& Technology, Longowal, Punjab, \\ India \\ Email: pspanesarrr@yahoo.com
}

Received August 20 ${ }^{\text {th }}, 2010$; revised October $9^{\text {th }}, 2010$; accepted October $16^{\text {th }}, 2010$

\begin{abstract}
Fermented dairy products have long been an important component of nutritional diet. Historically, fermentation process involved unpredictable and slow souring of milk caused by the organisms inherently present in milk. However, modern microbiological processes have resulted in the production of different fermented milk products of higher nutritional value under controlled conditions. These products represent an important component of functional foods, and intense research efforts are under way to develop dairy products into which probiotic organisms are incorporated to make them more valuable. This article provides an overview of the different starter cultures and health benefits of fermented dairy products, which can be derived by the consumers through their regular intake.
\end{abstract}

Keywords: Fermented Dairy Products, Starter Cultures, Nutrition, Benefits, Probiotics

\section{Introduction}

The role of fermented milk in human nutrition is well documented and the virtues of these products were known to man even during the ancient days of civilization. These products have long been an important component of nutritional diet. The medicinal and nutritional properties of various fermented foods have been experienced by several generations. However, the scientific community gave impetus to these beliefs in 1910, when Eli Metchnikoff suggested that man should consume milk fermented with lactobacilli to prolong his life. He postulated the desirable bacteria in the bulgarian milk that could help in suppressing the undesirable and disease causing bacteria in the intestine of human beings. The observation proved the way for exploring the potentials of lactic cultures and cultured products in the alleviation of human and animal disorders. Recently importance has been given to produce fermented milk with improved health attributes particularly the therapeutic properties of these products. A fermented milk product has been defined by the International Dairy Federation as the milk product prepared from skimmed milk or not with specific cultures. The microflora is kept alive until sale to the consumers and may not contain any pathogenic germs. The fermented milk products used in different countries may be broadly classified into three categories [1].

- Moderately sour type with pleasant aroma e.g. cultured milk.

- $\quad$ Sour and very high sour types e.g. curd, yoghurt.

- Acid-cum alcohol in addition to lactic acid e.g. kumiss and kefir.

The consumer's interest in fermented milk products is gaining momentum due to the development of new food processing techniques, changing social attitudes; scientific evidence of health benefits of certain ingredients $[2,3]$. Some cultured dairy foods such as bioghurt, yakult, actimel etc. are already marketed as therapeutic and dietetic products.

\section{Preparation of Fermented Dairy Products}

Fermented dairy products are made from milk of almost all domesticated milch animals since ages. Several new types of fermented milk products are becoming popular all over the world (Table 1). The traditional fermentations are taking place as a result of the activities of natural flora present in the food or added from the surroundings. Over the period, scientists have tried to isolate and study the characters of such desirable organisms. Among the bacteria, the most important dominant group bringing fermentation is lactic acid bacteria (Table 2). The lactic acid bacteria are naturally accepted as GRAS (Generally 
Table 1. Some important fermented dairy products.

\begin{tabular}{|c|c|c|c|}
\hline S.No. & Name & Type of Milk & Micro-organisms involved \\
\hline 1 & Curd & Buffalo's or cow’s milk & $\begin{array}{l}\text { L. lactis subsp. lactis } \\
\text { L. delbrueckii subsp. bulgaricus } \\
\text { L. plantarum } \\
\text { Streptococcus lactis } \\
\text { S. thermophilus } \\
\text { S. cremoris }\end{array}$ \\
\hline 2. & Yoghurt & Cow’s milk & $\begin{array}{l}\text { L. acidophilus } \\
\text { S. thermophilus } \\
\text { L. bulgaricus }\end{array}$ \\
\hline 3. & Cultured butter milk & Buffalo’s or cow’s milk & $\begin{array}{l}\text { S. lactis subsp. diacetylactis } \\
\text { S. cremoris }\end{array}$ \\
\hline 4. & Lassi & Buffalo’s or cow’s milk & L. bulgaricus \\
\hline 5. & Acdiophilus milk & Cows milk & L. acidophilus \\
\hline 6 & Bulgarian butter milk & Cow's milk & L. delbueckii subsp. bulgaricus \\
\hline 7. & Shrikhand & Buffalo's or cow’s milk & $\begin{array}{l}\text { S. thermophilus } \\
\text { L. bulgaricus }\end{array}$ \\
\hline 8. & Kumiss & $\begin{array}{l}\text { Mare's, camel's or } \\
\text { ass's milk }\end{array}$ & $\begin{array}{l}\text { L. acidophilus } \\
\text { L. bulgaricus } \\
\text { Saccharomyces } \\
\text { Micrococci }\end{array}$ \\
\hline 9. & Kefir & Sheep's, cow's, goat's or mixed milk & $\begin{array}{l}\text { S. lactis } \\
\text { Leuconostoc sp. } \\
\text { Saccharomyces } \\
\text { Kefir, Torula kefir, Micrococci }\end{array}$ \\
\hline 10. & Leben & Goats, sheep’s milk & $\begin{array}{l}\text { S. lactis } \\
\text { S. thermophilus } \\
\text { L. bulgaricus } \\
\text { Lactose fermenting yeast }\end{array}$ \\
\hline 11. & Cheese & Cow’s, Buffalo’s, goat's milk, sheep milk & $\begin{array}{l}\text { L. lactis subsp. lactis, } L \text {. lactis subsp. cremoris, } L \text {. } \\
\text { lactis subsp. diacetylactis, } S \text {. thermophilus, } L \text {. del- } \\
\text { bueckii subsp. bulgaricus } \\
\text { Priopionibacterium shermanii, } \\
\text { Penicillium roqueforti etc. }\end{array}$ \\
\hline
\end{tabular}

regarded as safe) for human consumption [4]. The general procedure used for the preparation of fermented milk products is shown in Figure 1. During fermentation, certain physical and chemical changes occur in the milk due to the growth and fermentative activities of lactic acid bacteria used as starter cultures (Table 3).

Milk products also serve as the important delivery vehicles for probiotic bacteria. The probiotic bacteria have a long history of association with dairy products. This is because some of the same bacteria that are associated with fermented dairy products also make their homes in different sites on the human body, including the mouth, the gastrointestinal tract etc. Some of these microbes, therefore, can play a dual role in transforming milk into a diverse array of fermented dairy products (yoghurt, cheese, kefir, etc.), and contributing to the important role of colonizing bacteria. Dairy products, represent a major portion of the total European functional foods market, and are at the forefront of probiotic developments. The growing interest of consumers towards therapeutic products has led to incorporation of probiotic cultures in different milk products. Within this sector, probiotic cultures have been incorporated in yoghurts and fermented milk products. The probiotic bacteria used in commercial products today are mainly members of the genera Lactobacillus and Bifidobacterium [5]. In the dairy markets, yoghurt with its existing health image is well positioned to capitalize on the growth of healthy foods [2].

\section{Nutritional Benefits}

The following describes some of the proposed health benefits of consumption of fermented/probiotic dairy products.

\subsection{Alleviation of Lactose Intolerance}

The inability of adults to digest lactose, or milk sugar, is prevalent worldwide. Consumption of lactose by those lacking adequate levels of lactase produced in the small intestine can result in symptoms of diarrhea, bloating, 
Table 2. Starter organisms for fermented dairy products [5].

\begin{tabular}{|c|c|c|c|c|c|}
\hline \multirow{2}{*}{ Micro-organism } & \multicolumn{3}{|c|}{ Growth temperature } & \multicolumn{2}{|c|}{ Lactic acid fermentation } \\
\hline & Minimum & Optimal & Maximum & Homofermentative & Heterofermatative \\
\hline $\begin{array}{l}\text { Lb. delbrueckii subsp. } \\
\text { bulgaricus }\end{array}$ & 22 & 45 & 52 & + & - \\
\hline $\begin{array}{l}\text { Lb. delbrueckii subsp. } \\
\text { lactis }\end{array}$ & 18 & 40 & 50 & + & - \\
\hline Lb. helveticus & 22 & 42 & 54 & + & - \\
\hline Lb. acidophilus & 27 & 37 & 48 & + & - \\
\hline Lb. kefir & 8 & 32 & 43 & - & + \\
\hline Lb. brevis & 8 & 30 & 42 & - & + \\
\hline Lb. casei subsp. casei & & 30 & & + & - \\
\hline S. thermophilus & 22 & 40 & 52 & + & - \\
\hline Lc. lactis subsp. lactis & 8 & 30 & 40 & + & - \\
\hline $\begin{array}{l}\text { Lc. lactis subsp. cre- } \\
\text { moris }\end{array}$ & 8 & 22 & 37 & + & - \\
\hline $\begin{array}{l}\text { Lc. lactis subsp. lactis } \\
\text { biovar. diacetylactis }\end{array}$ & 8 & $22-28$ & 40 & + & - \\
\hline $\begin{array}{l}\text { Ln. mesenteroides } \\
\text { subsp. cremoris }\end{array}$ & 4 & $20-28$ & 37 & - & + \\
\hline $\begin{array}{l}\text { Ln. mesenteroides } \\
\text { subsp. dextranicum }\end{array}$ & 4 & $20-28$ & 37 & - & + \\
\hline
\end{tabular}

Table 3. Changes in the milk constituents during lactic fermentation [1]

\begin{tabular}{ll}
\hline Decrease & Increase \\
\hline Lactose & Lactic acid \\
\hline Protein & Galactose \\
\hline Fat & Glucose \\
\hline Some vitamins & $\begin{array}{l}\text { Polysaccharides } \\
\text { Free amino acids; Flavouring compounds } \\
\end{array}$ \\
& Some vitamins; Some organic acids \\
& Antibacterial substances \\
\hline
\end{tabular}

abdominal pain and flatulence [6]. Milk with cells of $L$. acidophilus aids digestion of lactose by such persons. It has been documented that many lactose intolerant individuals are better able to consume fermented dairy products, such as yoghurt, with fewer symptoms than the same amount of unfermented milk. Yoghurt was found to be helpful in the digestion of lactose because the lactic acid bacteria used to make yoghurt produce lactase and digest the lactose [7].

\subsection{Protection against Gastrointestinal Infection}

Gastrointestinal infections including diarrhoea result from a change in the gut microflora caused by an invading pathogen. It is suggested that viable lactic acid bacteria interfere with the colonization and subsequent proliferation of food borne pathogens, thus preventing the manifestation of infection [1]. L. bulgaricus, L. acidophilus, S. thermophilus and B. bifidum have been implicated in this effect. The beneficial effects of lactic acid bacteria and cultured milk products have also been attributed to their ability to suppress the growth of pathogens either directly or through production of antibacterial substances. Antibiotics have been reported to kill normal bacteria as well, often resulting in disruption of the bacterial flora, leading to diarrhoea and other intestinal disturbances. Replenishing the flora with normal bacteria during and after antibiotic therapy seems to minimize disruptive effects of antibiotic use. Probiotics have been reported to effective in prevention of various gastrointestinal infections [8]. There are reports of benefits for sufferers of rotavirus infection, traveler's diarrhoea \& antiobiotic induced diarrhea.

\subsection{Anticarcinogenic Effect}

It has been reported that fermented milk products can protect against certain types of cancers. Some of epidemiological support is also there. Consumption of yoghurt, gouda cheese, butter milk protect against breast cancer. Animal studies have shown that lactic acid bacteria exert anticarcinogenic effect either by prevention of cancer initiation or by suppression of initiated cancer. Anticarcinogenic effects of yoghurt and milk fermented with $L$. acidophilus have been reported in mice. Different potential mechanisms by which lactic acid bacteria exert antitumor effects have been suggested such as changes in 


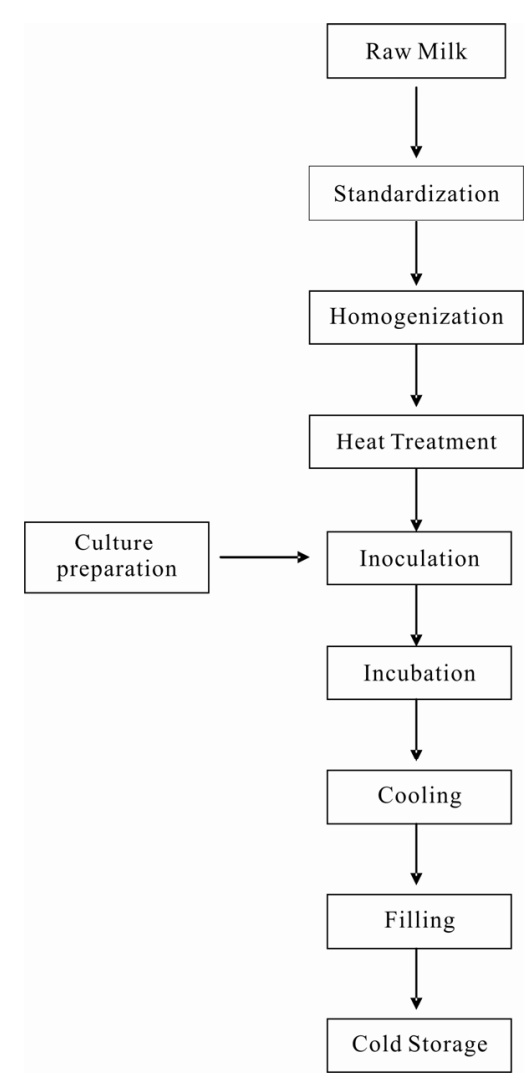

Figure 1. General steps involved in the preparation of fermented dairy products.

faecal enzymes thought to be involved in colon carcinogenesis, cellular uptake of mutagenic compounds, reducing the mutagenicity of chemical mutagens and suppression of tumors by improved immune response [9].

\subsection{Immune System Stimulation}

The immune system provides the primary defense against microbial pathogens that have entered our bodies. The immunostimulatory effects of yoghurt are believed to be due to its bacterial components [1]. Animal and some human studies have shown an effect of yoghurt or lactic acid bacteria on enhancing levels of certain immunoreactive cells or factors. Milk components such as whey protein, calcium, certain vitamins and trace elements are also capable of influencing immune system. Studies have shown that cytokine production, phagocytic activity, antibody production, T-cell production etc. are increased with yoghurt consumption or with lactic acid bacteria.

\subsection{Lowering of Serum Cholesterol}

Reports indicate that fermented milk products to have hypocholesteraemic effect [10]. It is suggested that intake of large quantities of fermented milk furnish factors that impair the synthesis of cholesterol. It has been re- ported that L. acidophilus has exhibited the ability to lower serum cholesterol levels. This promotes the potential healthful aspects of dairy products fermented with $L$. acidophilus (or other lactic acid bacteria), since hypercholestermia is considered to be one of the major factors contributing to cardiovascular disease. However, it is likely that some strains may demonstrate this property while others do not.

\subsection{Alleviation of Constipation}

Constipation is common problem in subjects consuming the western diet and also in elderly people. Several studies with lactobacillus preparation and fermented milks have been published $[8,11]$. Reported benefits include alleviation of constipation using L. acidophilus NCDO 1748, L. casei Shirota and Lactobacillus GG.

\subsection{Antihypertensive Activity}

Casein hydrolysate, produced by an extracellular proteinase from L. helveticus (CP790) has been reported to show antihypertensive activity in rats. Two antihypertensive peptides have also been purified from sour milk fermented with L. helveticus and Saccharomyces cerevisiae. These two peptides inhibit angiotensin-converting enzyme that converts angiotensinogen I to angiotensinogen II, which is a potent vasoconstrictor [12]. It has been reported that consumption of certain lactobacilli, or products made from them, may reduce blood pressure in mildly hypertensive people.

\subsection{Antiallergenic Qualities}

Probiotics may help prevent allergic reactions in individuals at high risk of allergies, such as food allergies. Probiotic bacteria help to reinforce the barrier function of the intestinal wall, thereby possibly preventing the absorption of some antigens $[8,13]$.

\section{Conclusions}

Cultured dairy products have been providing vital importance in the human diet. However, further research into areas of the products as anticarcinogens, antitumor agents, and in the area of cholesterol will yield even more potential for cultured dairy products as an important component of human nutrition. However, careful selection of specific strains combined with proper production and handling procedures will be necessary to ensure that desired benefits are provided to consumers. At large, the opinion is in favour of probiotics and fermented foods. The challenge would be to find out the most suitable candidate organism for fermentation, select different protective and carrier media, evolve a suitable technology to design foods which contain and maintain large populations of viable bio-active organisms during 
processing and post harvest processing periods and have longer shelf life. The products must also be readily acceptable as regular foods. Definitely, fermented dairy products containing probiotic combinations promise a healthy, "functional food package" for improved longterm health benefits.

\section{REFERENCES}

[1] D. N. Gandhi, "Fermented Dairy Products and Their Role in Controlling Food Borne Diseases” In: S. S. Marwaha and J. K. Arora, Eds., Food Processing: Biotechnological Applications, Asiatech Publishers Inc., New Delhi, 2000, pp. 209-220.

[2] C. Stanton, G. Gardiner, H. Meehan, K. Collins, G. Fitzgerald, P. B. Lynch and R. P. Ross, "Market Potential for Probiotics," American Journal of Clinical Nutrition, Vol. 73, No. 2, 2001, pp. 476S-483S.

[3] H. Korhonen and A. Pihlanto, "Bioactive Peptides: Production and functionality,” International Dairy Journal, Vol. 16, No. 9, 2006, pp. 945-960. doi:10.1016/j.idairyj.2005.10.012

[4] M. Aguirre and M. D. Collins, "Lactic Acid Bacteria and Human Clinical Infection," Journal of Applied Bacteriology, Vol. 75, No. 2, 1993, pp. 95-107.

[5] K. J. Heller, "Probiotic Bacteria in Fermented Foods: Product Characteristics and Starter Organisms," American Journal of Clinical Nutrition, Vol. 73, No. 2, 2001, pp. 374S-379S.

[6] P. S. Panesar, R. Panesar, R. S. Singh, J. F. Kennedy and H. Kumar, "Microbial Production, Immobilization and Applications of $\beta$-D-Galactosidase," Journal of Chemical Technology and Biotechnology, Vol. 81, No. 4, 2006, pp. 530-543. doi:10.1002/jctb.1453

[7] S. E. Gilliland, "Influence of Bacterial Starter Cultures on Nutritional Value of Foods: Improvement of Lactose Digestion by Consuming Foods Containing Lactobacilli,” Cultured Dairy Products Journal, Vol. 20, No. 2, 1985, pp. 28-33.

[8] P. S. Panesar, G. Kaur, R. Panesar and M. B. Bera, "Synbiotics: Potential Dietary Supplements in Functional Foods,” FST Bulletin, Food Science Central, IFIS Publishing, UK, April, 2009.

http://www.foodsciencecentral.com/fsc/ixid15649

[9] A. Hosono, T. Kashina and T. Kada, "Antimutagenic Properties of Lactic Acid Cultured Milk on Chemical and Faecal Mutagens,” Journal of Dairy Science, Vol. 69, No. 9, 1986, pp. 2237-2242. doi:10.3168/jds.S0022-0302(86)80662-2

[10] K. K. Grunewald, "Serum Cholesterol Levels in Rats Fed Skim Milk Fermented by Lactobacillus Acidophilus,” Journal of Food Science, Vol. 47, No. 6, 1992, pp. 2078-2079. doi:10.1111/j.1365-2621.1982.tb12955.x

[11] T. Ogawa, R. Hirai, H. Nakakuni, Y. Sato, S. Wakisaka, M. Tachibana, H. Tominaga, M. Kurata and K. Matsubayashi, "Clinical Experience with the Use of the High Concentration Lactic Acid Bacteria Preparation LP-201 to Treat Constipation,” Clinical Report, Vol. 8, 1974, pp. 1085-1092.

[12] M. Maeno, N. Yamamoto and T. Takano, "Identification of an Antihypertensive Peptide from Casein Hydrolysate Produced by a Proteinase from $L$. helveticus CP790,” Journal of Dairy Science, Vol. 79, No. 8, 1996, pp. 1316-1321. doi:10.3168/jds.S0022-0302(96)76487-1

[13] P. V. Kirjavainen, S. J. Salminen and E. Isolauri, "Probiotic Bacteria in the Management of Atopic Disease Underscoring the Importance of Viability," Journal of Pediatric Gastroenterology and Nutrition, Vol. 36, No. 2, 2003, pp. 223-227. doi:10.1097/00005176-200302000-00012 